\title{
Pembuatan Alat Otomatis Hand Sanitizer sebagai Salah Satu Antisipasi Penyebaran COVID-19 di Politeknik Negeri Batam
}

\author{
B. Budiana*, Abdullah Sani, Daniel Sutopo Pamungkas, Muhammad Prihadi Eko Wahyudi, \\ Lindawani Siregar, Sumantri Kurniawan Risandriya, Kamarudin, Nur Sakinah Asaad, Nadhrah Wivanius, \\ Rizky Pratama Hudhajanto, Aditya Gautama Darmoyono, Rahmi Mahdaliza, Ardian Budi Kusuma Atmaja, Arif \\ Wahyu Budiarto, Yulfiana Harini, Bayu Prayogo Setiawan, Indra Daulay, Dodi Radot Lumbantoruan
}

Teknik Elektro, Politeknik Negeri Batam, Batam, Indonesia

"Email: budiana@polibatam.ac.id

\begin{abstract}
Abstrak - COVID-19 menyerang manusia pada akhir tahun 2019. Penyebaran COVID-19 terjadi melalui droplet/cairan yang keluar dari mulut/hidung manusia. Antisipasi penyebaran COVID-19 dilakukan dengan menerapkan pola hidup bersih dan sehat. Salah satu caranya adalah dengan mencuci tangan menggunakan hand sanitizer. Penggunaan hand sanitizer di tempat umum memungkinkan terjadinya kontak fisik antar pengguna sehingga diperlukan cara untuk mengurangi kontak fisik tersebut. Cara yang bisa diterapkan adalah dengan menggunakan hand sanitizer otomatis. Prinsip dari hand sanitizer otomatis ini adalah ketika tangan didekatkan dengan botol hand sanitizer maka secara otomatis cairan akan keluar dengan sendirinya ke telapak tangan. Berdasarkan hasil penelitian yang telah dilakukan, hand sanitizer telah berhasil dibuat dan dapat digunakan di Politeknik Negeri Batam.
\end{abstract}

Kata kunci: COVID-19, hand sanitizer, automatic

\section{LATAR BELAKANG}

Pada akhir tahun 2019, terdapat virus baru yang menyerang manusia, tepatnya di kota Wuhan, Tiongkok [1-3]. Virus tersebut dikenal dengan nama 2019-nCov atau bisa disebut juga COVID 19. Sebelumnya, virus dengan jenis coronavirus telah menyerang manusia pada tahun 2002 yaitu SARS CoV dan pada tahun 2012 yaitu MERS CoV [1],[4-6]. Virus-virus yang telah berkembang tersebut menyerang manusia dan mengakibatkan kematian [7].

Kasus COVID-19 terkonfirmasi pertama kali di Indonesia pada awal Maret 2020. Jumlah pasien yang terkonfirmasi positif COVID-19 per tanggal 12 Desember 2020 adalah 598933 dengan jumlah pasien sembuh 491975 dan jumlah pasien yang meninggal 18336 [8]. Jika dilihat berdasarkan sebaran provinsi, kasus COVID-19 ini dapat dilihat pada Gambar 1.

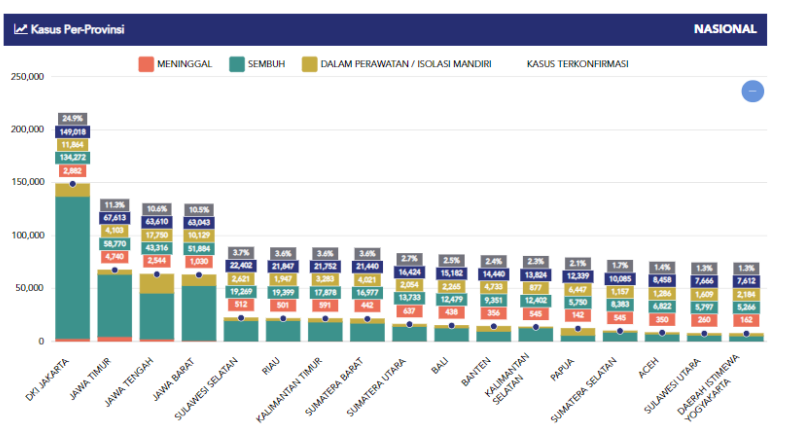

Gambar 1. Data kasus COVID-19 secara nasional berdasarkan pada kasus tiap provinsi [8]

Salah satu provinsi yang terkonfirmasi positif Covid-19 di Indonesia yaitu Kepulauan Riau. Perkembangan kasus meninggal per hari di Kepulauan Riau dapat dilihat pada Gambar 2.

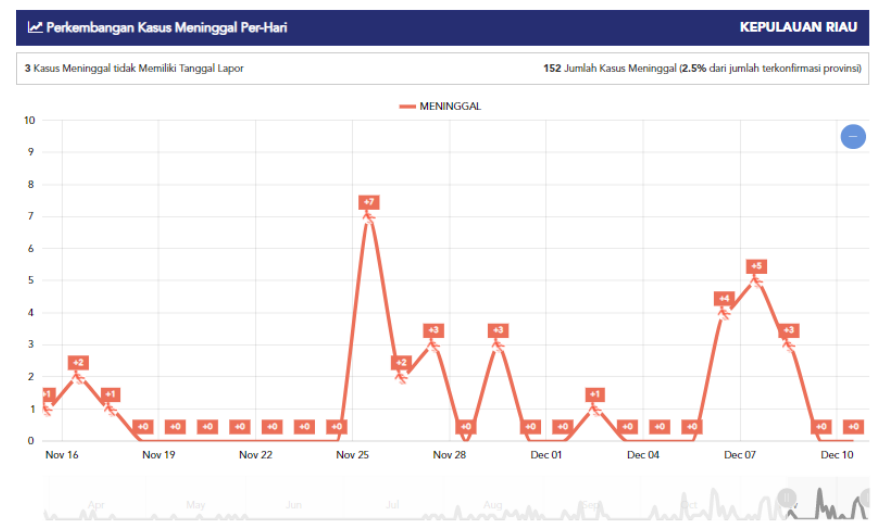

Gambar 2. Data kasus COVID-19 secara nasional berdasarkan pada perkembangan kasus meninggal per hari di kepulauan Riau [8] 
Berdasarkan pada jumlah pasien yang terkonfirmasi positif COVID-19 dan juga data sebaran di seluruh provinsi, tentunya diperlukan suatu cara yang optimal untuk mengurangi ataupun antisipasi terkait dengan penyebaran COVID-19. Salah satu cara yang dapat dilakukan oleh masyarakat adalah melalui penerapan hidup sehat dan bersih. Penerapan hidup sehat dan bersih dapat dilakukan dengan membersihkan tangan secara teratur dengan menggunkan sabun atu hand sanitizer [9].

Terdapat berbagai penelitian yang menunjukan bahwa membersihkan tangan dengan menggunakan hand sanitizer dapat membunuh kuman dan bakteri. Namun, penggunaan bersama hand sanitizer ditempat umum dapat berpotensi dalam menularkan COVID-19. Potensi ini terjadi ketika pengeluran cairan hand sanitizer dari kemasan dengan menekan botol hand sanitizer. Berdasarkan hal tersebut, tim peneliti akan membuat suatu alat pengeluaran hand sanitizer dari kemasan dengan otomatis. Tujuan dari pembuatan alat tersebut adalah untuk mengurangi kontak yang dilakukan oleh pengguna pada botol hand sanitizer. Alat yang sudah dibuat oleh tim peneliti akan diterapkan di Politeknik Negeri Batam.

Politeknik Negeri Batam merupakan perguruan tinggi negeri yang terdapat di Kepaulauan Riau. Politeknik ini merupakan salah satu contoh tempat bertemunya masyarakat dari berbagai tempat. Sehingga potensi penyebaran COVID-19 ini sangat tinggi terjadi. Dengan adanya hand sanitizer yang telah dibuat melalui penelitian ini, diharapkan potensi penyebaran COVID-19 di Politeknik Negeri Batam dapat diantisipasi atau dapat dikurangi penyebarannya.

\section{KAJIAN PUSTAKA}

Terdapat beberapa cara untuk membersihkan tangan dari kuman dan bakteri, diantaranya adalah dengan mencuci tangan menggunakan sabun dan air serta mencuci tangan menggunakan hand sanitizer. Hand sanitizer secara umum digolongkan menjadi dua macam yaitu hand sanitizer berbahan dasar alkohol (ABHS) dan hand sanitizer yang tidak berbahan dasar alkohol (NABHS) [10]. Penelitian tentang efektifitas hand sanitizer untuk membunuh kuman dan bakteri telah dilakukan oleh beberapa peneliti diantaranya adalah efektifnya penggunaan hand sanitizer yang digunakan di kerajaan Arab Saudi terhadap patogen bakteri [11], penggunaan benzalkonium chloride hand sanitizer yang dapat mereduksi jumlah bakteri koloni Staphylococcus aureus [12], Tidak ada perbedaan yang signifikan hand sanitizer yang menggunakan bahan alkohol dan tidak menggunakan bahan alkohol dalam mereduksi jumlah koloni bakteri E. Coli [13].

Selain dari penelitian yang berkenaan dengan efektivitas hand sanitizer dalam membunuh kuman dan bakteri, terdapat penelitian mengenai rancang bangun alat hand sanitizer otomatis diantaranya adalah pembuatan hand sanitizer otomatis yang kompatibel terhadap berbagai variasi wadah [14], penggunaan Arduino untuk menghitung jarak antara sensor dengan tangan yang diletakan dibawahnya menggunakan fungsi waktu [15], pembuatan smart hand sanitizer dengan menggunakan ATmega328P [16], pencuci tangan dan pengering otomatis [17].
Secara umum sistem hand sanitizer otomatis memiliki sistem yang hampir sama pada pencuci tangan otomatis saat mengeluarkan sabun atau mengeluarkan sanitizer. Komponen yang biasa digunakan dalam pembuatan hand sanitizer otomatis terdiri dari sensor infrared, Arduino, modul relay, pompa sabun dan air serta hand dryer. Sensor Infrared mendeteksi jarak pada slot sabun dan mengirimkan input ke Arduino. Arduino menerima input dan mengirimkan data ke modul program untuk di proses. Modul program melakukan pemprosesan data dan menghasilkan instruksi-instruksi yang kemudian dikirim kembali ke Arduino. Sedangkan Arduino memberikan output ke modul relay [17].

\section{Metodologi}

Tahapan penelitian dalam pembuatan hand sanitizer otomatis ditunjukan pada Gambar 3.

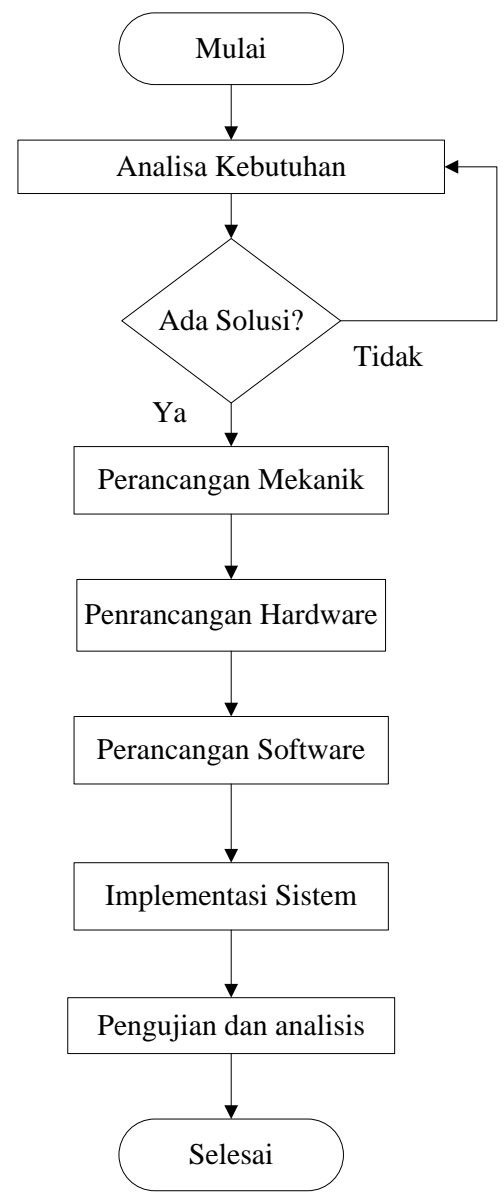

Gambar 3. Diagram Alir penelitian pembuatan hand sanitizer otomatis

\section{A. Analisis Kebutuhan}

Analisis dilakukan untuk melihat kebutuhan berbagai komponen yang akan digunakan pada sistem meliputi mekanik, hardware, software, hingga sistem keseluruhan. Analisis juga mendokumentasikan aktivitas sistem informasi meliputi input, pemprosesan, output, penyimpanan dan pengendalian. Analisis kebutuhan sistem sebagai bagian dari studi awal yang bertujuan untuk mengidentifikasi masalah dan kebutuhan spesifik sistem. 
Kebutuhan spesifik sistem adalah spesifikasi mengenai hal-hal yang akan dilakukan sistem ketika diimplementasikan.

\section{B. Perancangan Mekanik}

Perancangan mekanik terdiri dari desain mekanik pada alat hand sanitizer otomatis. Desain disesuaikan dengan kebutuhan hardware dan penempatan hand sanitizer yang akan digunakan. Gambar 4 menujukkan desain mekanik dari hand sanitizer otomatis yang digunakan.

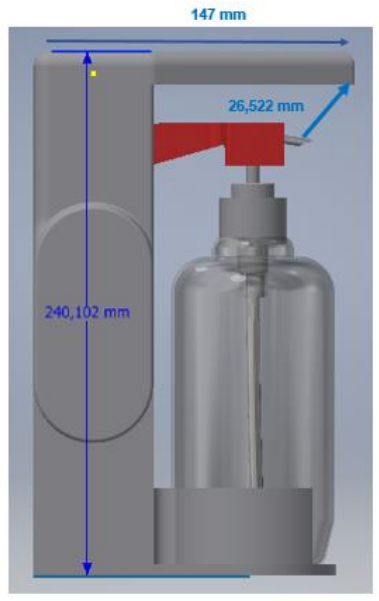

Gambar 4. Rancangan pembuatan hand sanitizer otomatis yang akan digunakan di Politeknik Negeri Batam.

\section{Perancangan Hardware}

Desain hardware elektronik meliputi adaptor 5 Volt 3 A untuk supply seluruh kebutuhan pada servo, sensor, mikrokontroler ESP 32.

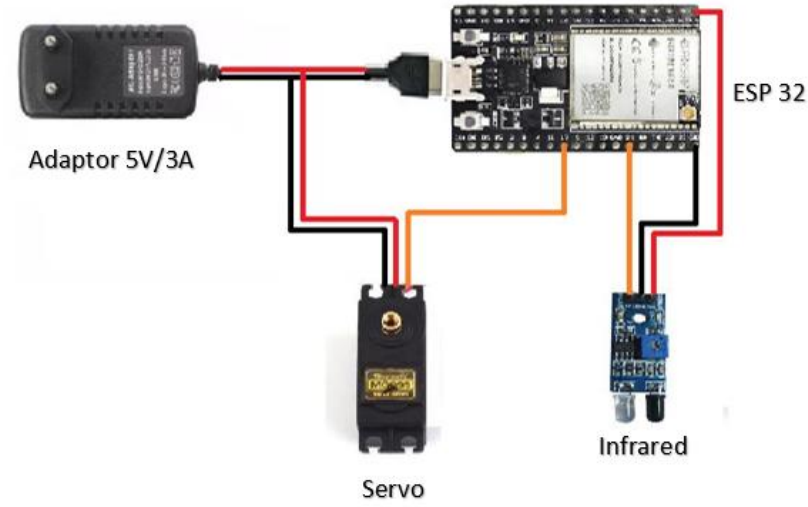

KETERANGAN :

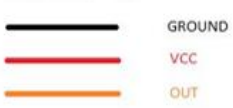

Gambar 5. Desain perancangan hardware hand sanitizer otomatis yang akan digunakan di Politeknik Negeri Batam

Input dari mikrokontroler ESP 32 adalah sensor infrared. Sedangkan output dari mikrokontroler ESP 32 yaitu motor servo. Sensor infrared mentedeteksi adanya tangan. Sehingga memicu motor servo berputar dan mengeluarkan antiseptik hand sanitizer. Sensor infrared digunakan sebagai pendeteksi gerakan tangan. Motor servo sebagai aktuator, dimana motor servo berfungsi untuk mengatur keluarnya hand sanitizer dari botol.

\section{Perancangan Software}

Perancangan software atau program berkaitan dengan bagaimana hand sanitizer otomatis mampu bekerja. Saat sistem menyala, sensor menginisialisasi untuk mendeteksi adanya objek berupa tangan dalam jangkauan. Ketika ada objek yang terdeteksi maka sensor infrared mengirim sinyal ke ESP 32 kemudian mengaktifkan motor servo. Sebaliknya, jika tidak mendeteksi adanya objek maka sistem akan stanby. Flowchart program hand sanitizer otomatis dapat dilihat pada Gambar 6.

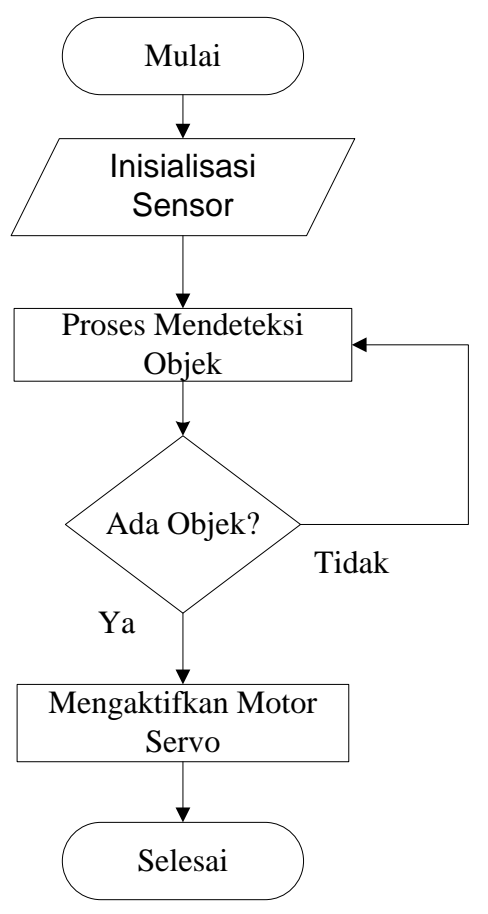

Gambar 6. Flowchart program hand sanitizer otomatis

\section{E. Implementasi sistem}

Pada tahap ini merupakan keseluruhan perancangan sistem yang akan diimplementasikan dalam satu integrasi sistem sehingga hand sanitizer otomatis dapat berfungsi sesuai yang direncanakan.

\section{F. Pengujian dan analisis}

Pengujian dilakukan pada perangkat keras (hardware) dan software yang digunakan. Software yang digunakan bertujuan untuk mengetahui kinerja alat sehingga dapat diimplementasikan dalam satu kesatuan sistem. Selain dari itu, pengujian dan analisis bertujuan untuk menemukan kompatibilitas dari penggunaan hardware, software dan mekanik yang telah dibuat.

\section{HASIL DAN DISKUSI}

Berdasarkan perancangan mekanik, hardware dan software yang telah dilakukan, ringkasan hasil yang dicapai dapat ditunjukan pada Tabel I. 
TABEL I

KETERCAPAIAN DAN INDIKATOR ALAT

\begin{tabular}{|c|c|c|}
\hline Modul & $\begin{array}{l}\text { Ketercapaian } \\
\text { Fungsi }\end{array}$ & Indikator \\
\hline Power Supply & $100 \%$ & Output tegangan \\
\hline $\begin{array}{l}3.3 \mathrm{~V} \text { dan } 5 \mathrm{~V} \\
\text { pada ESP32 }\end{array}$ & & $5 \mathrm{~V}$ dan $3.3 \mathrm{~V} 5 \%$ toleransi \\
\hline Regulator 5V3A & $100 \%$ & $\begin{array}{l}\text { Output tegangan } \\
5 \mathrm{~V} \text { dan } 5 \% \text { toleransi }\end{array}$ \\
\hline Motor Servo & $100 \%$ & $\begin{array}{l}\text { Motor servo dapat bergerak } \\
\text { melalui pin PWM }\end{array}$ \\
\hline Sensor Infrared & $100 \%$ & $\begin{array}{l}\text { Membaca objek berupa tangan } \\
\text { melalui pin digital/analog }\end{array}$ \\
\hline
\end{tabular}

Hasil dari perancangan mekanik, hardware dan software yang menjadi kesatuan sistem dan dapat berfungsi dapat dilihat pada Gambar 7.

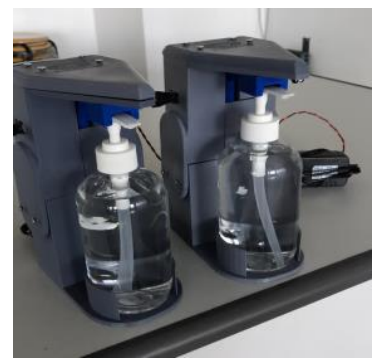

Gambar 7. Hand sanitizer otomatis yang telah dibuat

Hand sanitizer otomatis yang telah dibuat dapat digunakan sesuai yang diharapakan, ketika tangan diletakan pada ujung bawah botol, cairan hand sanitizer akan keluar secara otomatis dari dalam wadah botol. Jarak minimal telapak tangan terhadap lubang tempat pengeluaran hand sanitizer $\pm 5 \mathrm{~cm}$. Pengeluaran cairan hand sanitizer otomatis dari dalam botol berguna untuk mengurangi kontak tangan pengguna terhadap tempat tekan botol dari pengguna yang lain. Sehingga diharapkan dengan adanya sistem otomatis ini dapat mengurangi terjadinya penyebaran COVID-19 di Politeknik Negeri Batam.

\section{KESIMPULAN}

Berdasarkan metode penelitian yang telah dilakukan, hand sanitizer otomatis telah berhasil dibuat dengan menggunakan perancangan mekanik, hardware dan software yang telah digunakan. Sistem perancangan tersebut bekerja secara terintegrasi, kompatibel dan optimal. Jarak minimal telapak tangan terhadap lubang pengeluaran hand sanitizer adalah \pm 5 $\mathrm{cm}$. Dengan adanya alat hand sanitizer otomatis yang telah berhasil dibuat, tim peneliti akan menerapkannya di Politeknik Negeri Batam sebagai antisipasi penyebaran COVID-19.

\section{UCAPAN TERIMA KASIH}

Penulis mengucapakan terima kasih kepada Unit P3M Politeknik Negeri Batam yang telah memberikan dukungan finasial melalui Program Pengabdian Dosen pada tahun 2020. Selain dari itu, penulis mengucapkan terima kasih kepada jurusan Teknik Elektro yang telah memberikan dukungan selama proses penelitian dilakukan.

\section{DAFTAR PUSTAKA}

[1] Y. Yuliana, "Corona virus diseases (Covid-19): Sebuah tinjauan literatur," Wellness Healthy Mag., vol. 2, no. 1, Art. no. 1, Mar. 2020.

[2] W. Liu, X.-G. Yue, and P. Tchounwou, "Response to the COVID-19 Epidemic: The Chinese Experience and Implications for Other Countries," Int. J. Environ. Res. Public. Health, vol. 17, p. 2304, Mar. 2020, doi: 10.3390/ijerph17072304.

[3] Z. Shangguan, M. Wang, and W. Sun, "What Caused the Outbreak of COVID-19 in China: From the Perspective of Crisis Management," Int. J. Environ. Res. Public. Health, vol. 17, p. 3279, May 2020, doi: 10.3390/ijerph17093279.

[4] F. Setiawan, H. Puspitasari, J. Sunariani, and A. Yudianto, "Molecular Review Covid19 from the Pathogenesis and Transmission Aspect," J. Kesehat. Lingkung., vol. 12, no. 1si, Art. no. 1si, Sep. 2020, doi: 10.20473/jkl.v12i1si.2020.93-103.

[5] S. Navas-Martin and S. Weiss, "Coronavirus replication and pathogenesis: Implications for the recent outbreak of severe acute respiratory syndrome (SARS), and the challenge for vaccine development," J. Neurovirol., vol. 10, pp. 75-85, May 2004, doi: $10.1080 / 13550280490280292$.

[6] R. Djalante et al., "Review and analysis of current responses to COVID19 in Indonesia: Period of January to March 2020," Prog. Disaster Sci., vol. 6, p. 100091, Apr. 2020, doi: 10.1016/j.pdisas.2020.100091.

[7] S. Garima and N. Singh, "Fatality in COVID 19: an overview of causes of death and organ involvement," Int. J. Adv. Med., vol. 7, p. 1190, Jun. 2020, doi: 10.18203/2349-3933.ijam20202598.

[8] S. P. COVID-19, "Peta Sebaran | Satgas Penanganan COVID-19," covid19.go.id. https://covid19.go.id/peta-sebaran (accessed Dec. 11, 2020).

[9] P. Liu, Y. Yuen, H.-M. Hsiao, L.-A. Jaykus, and C. Moe, "Effectiveness of Liquid Soap and Hand sanitizer against Norwalk Virus on Contaminated Hands," Appl. Environ. Microbiol., vol. 76, no. 2, pp. 394399, Jan. 2010, doi: 10.1128/AEM.01729-09.

[10] A. Golin, D. Choi, and A. Ghahary, "Hand sanitizers: A Review of Ingredients, Mechanisms of Action, Modes of Delivery, and Efficacy Against Coronaviruses," Am. J. Infect. Control, vol. 48, Jun. 2020, doi: 10.1016/j.ajic.2020.06.182.

[11] Y. Ali, "To Study The Effect Of Hand sanitizers Used In Kingdom Of Saudi Arabia Against The Common Bacterial Pathogens," IRJNAS, vol. 2, Feb. 2015.

[12] S. Bondurant, T. McKinney, L. Bondurant, and L. Fitzpatrick, "Evaluation of a benzalkonium chloride hand sanitizer in reducing transient Staphylococcus aureus bacterial skin contamination in health care workers," Am. J. Infect. Control, vol. 48, no. 5, pp. 522-526, May 2020, doi: 10.1016/j.ajic.2019.08.030.

[13] M. Smieschek, A. Stollenwerk, P. Juptner, S. Kowalewski, T. Orlikowsky, and M. Schoberer, "Evaluating Hand Disinfection with Alcohol-Based Hand sanitizers Using Thermal Imaging," p. 8.

[14] J. Lee, J.-Y. Lee, S.-M. Cho, K.-C. Yoon, Y. J. Kim, and K. G. Kim, "Design of Automatic Hand sanitizer System Compatible with Various Containers," Healthc. Inform. Res., vol. 26, no. 3, pp. 243-247, Jul. 2020, doi: 10.4258/hir.2020.26.3.243.

[15] A. S, "Review on Automatic Sanitizer Dispensing Machine," Int. J. Eng. Res., vol. V9, Jul. 2020, doi: 10.17577/IJERTV9IS070307.

[16] E. Edozie, W. Janat, and Z. Kalyankolo, "Design and Implementation of a Smart Hand sanitizer Dispenser with Door Controller using ATMEGA328P," vol. 4, no. 6, p. 5, 2020.

[17] H. Hendri, "Pembersih Tangan Otomatis Dilengkapi Air, Sabun, Handdryer Dan Lcd Menggunakan Sensor Infrared Berbasis Arduino," Teknologi, vol. 8, no. 1, Art. no. 1, Feb. 2019. 